Julieta Rotaru*

\title{
Towards a Methodology for Applying the paribhāṣās in the Kauśikasūtra (II)
}

\author{
https://doi.org/10.1515/asia-2018-0014
}

Abstract: The Kauśikasūtra has three sets of general rules, the first two (1.1-8 cum 1.9-23) consecutively opening up the sütra-text, having an application to the adjoining context, and the third one (7.1-9.7) being seemingly prescribed for the rest of the work. The understanding of the Kauśikasūtra draws hugely on ascertaining the right meaning of these paribhāṣās. The general rule 8.10 is an interesting example of such crux filologorum, wherein, regardless the emendation, the enouncement apparently bears little meaning and the paribhāssā, as a whole, seems inapplicable. The paper discusses sixteen cases whereto the paribhasșā 8.10 might be applied, starting from the instances thus indicated by the two commentators, Dārila and Keśava. In subsidiary, another subject is elucidated, the set of rites called manthāntāni karmāni, which, although there is no paribhāṣa a regulating their function, they are prescribed by the sequence of rites 11.11-11.15, and are to be applied in the specified context. This is an example of the efforts done by the subsequent redactor(s) of the Kauśikasūtra, who have added general rules to elucidate the concise and obscure sūtra-text: an unspecified general rule (11.11ff) inserted in the adjoining context, and a specified, but redundant general rule (8.10) employed in the appropriate section, with little care for the consistency of the editorial work.

Keywords: Kauśikasūtra, paribhāṣāviniyoga (application of the general rule), anuvrtti (supplying the missing term from previous passage), emendation, text criticism

The paper was presented in the Vedic Section of the Fourteenth World Sanskrit Conference, Kyoto, September 1-5, 2009, and it is the third in an ongoing study on the employment of the general rules of the Kauśikasūtra, the first, Rotaru (2008) 2010 and the other, Rotaru 2016.

*Corresponding author: Julieta Rotaru, Centre for Baltic and East European Studies (CBEES), Södertörn University, Stockholm, Alfred Nobels Allé 7, 14189 Huddinge, Sweden.

E-mail: julieta.rotaru@sh.se 


\section{Introduction}

The Kauśikasūtra (hereafter KauśS) opens with a set of general rules giving indications about the sources of the text (1.1-8). Then another set of paribhāșās with a special character follows, applicable only in the rituals of the full moon and new moon that are prescribed subsequently (1.14-6.37). After the description of these rituals, three chapters consisting of rules with a more general character (7.1-9.7) follow. Their applicability (adhikära) starts from this point on and it seems that they are prescribed for the whole sūtra-text. ${ }^{1}$ There are also several meta-rules which are inserted in different places, regularly in juxtaposition to the sūtras to which they apply: KauśS 11.11, 12.4, 21.21, etc.

Bloomfield considers that the text was compiled at a certain time out of different materials, with an evident individual character, and that the redactor(s) did not try or did not succeed to harmonize and unify the discrepancies. ${ }^{2}$ In this way it is possible that the general rules would be applied strictly in some passages and loosely or at all in others. ${ }^{3}$ While translating the so-called magical rites of the Kauss Caland has fathomed and specifically pointed out how essential is the understanding of the paribhāṣās for the overall comprehension of the sūtra-text. Yet, a systematic study ${ }^{4}$ regarding a methodology of the application of the general rules in the KauśS is wanting. ${ }^{5}$

In my connected studies, previously mentioned, I have raised the questions whether Kauśika had in mind some of these meta-rules at the time of his composition and if the later redactor(s) attempted to maintain a high degree of consistency in applying them to the newly introduced fragments. The present work evaluates the paribhāṣā 8.10, apparently added by a second redaction and maladroitly applied by the two medieval commentators.

The existing edition of the KauśS reads: viśaye yathāntaram. Bloomfield emends the sūtra as viśaye, against the unanimous reading of the eight MSS. of the KauśS, vișaye. The emendation is retained by Bahulkar (1990: 122) in his edition of the first adhyāya of the KauśS on the basis of new MSS., all having the

1 Bloomfield 1889: xxvii.

2 Bloomfield 1889: xxii ff.

3 Based on the irregular application of the paribhāṣa 7.8 , corroborated with other arguments, Bloomfield (1889: xxvi) postulates the later incorporation of the fourteenth chapter into the main corpus of the Kauśs.

4 The subject is dealt with by Bahulkar (1977, taken up again in 1994: 2-7), with regard to the paribhāṣās 8.7 and 8.21. The difficult sūtras are translated and explained, and some instances of their viniyoga are mentioned. The applicability of these meta-rules is verified while identifying a certain Śaunakin pratīka in the KauśS and other Atharvavedic ritual texts in Rotaru 2012.

5 Caland 1900: v. 
same reading as vișaye. In addition, I have consulted four new manuscripts ${ }^{6}$ which unanimously have the lectio vișaye. Two of them read vișaye yatthotaram, variant present also in two manuscripts ${ }^{7}$ used by Bahulkar (1990: 122), who does not report the same.

The nityakarmadhāra yathāntaram is a cliché found in many sāstric works, where the recurrent stereotyped passages are referred, chiefly due to the oral textual transmission, by the "as above" technique. It is surprising that at least four scribes of the KauśS have understood yatthotaram, which conveys precisely the opposite. ${ }^{8}$

Caland translates the paribhāṣā 8.10 and comments in the following way:

8.10. Bei Bezugnahme (mache man es) wie in der Nähe (angedeutet worden ist). - Ein sehr schwieriges Sutra. Die von BR vorgeschlagene Deutung von yathāntaram ("je nach dem Zwischenraume") hilft uns nichts. Da alle HSS. vișaye (nicht viśaye so Bloomfield) bieten und sowohl Dārila und Keśava immer vișaye mit ș citiren, haben wir dieses für das Richtige $\mathrm{zu}$ halten. Ich vermuthe, dass unser Sūtra diese Bedeutung hat: "wo in den Vorschiften dieses Ritualtextes der Ausdruck, dadurch dass er elliptisch ist, auf Anderes Bezug nimmt, soll man die Ellipsis mit den Terminis ergänzen, die am meisten in der Nähe zuvor erwähnt worden sind." So ist, nach Dārila, bei 26.21 als Prädikat badhnāti zu ergänzen (es läge indessen näher, an $13.3 \mathrm{zu}$ denken, wo gleichfalls badhnāti, nach 13.2, hinzuzudenken ist); 13.1 ist zu hastinam als Prädikat aus 12.14 upatișţhate zu entnehmen: antaratvāt (Dārila). Kauś. 46.7 wird nicht ausdrücklich gesagt, was weiter nach der Weihung des śāntyudaka zu machen sei; hier sollen nun aber die Handlungen von 39.8-9 anschliessen. Auf Grund dieser Stellen möchte man fast meinen, dass yathāntaram bedeute: "so wie an den analogen Stellen”. Ist diese Deutung möglich? ${ }^{9}$

6 Two from Oriental Institute, Baroda, accession nos. 889 and 6854 and two from Staatsbibliothek, München, accession nos. 177 and 178.

7 Bhandarkar Oriental Research Institute 4/1866-68 and Bhandarkar Oriental Research Institute 5/1866-68.

8 Dr. M.G. Dhadphale (B.O.R.I.) has commented my Kyoto presentation pointing out that the Pali word to indicate "as above" is hețthānaya, "as in the below way", sense derived from the actual copying of the MSS., wherein the completed folio would go down in the basket on which the subsequent ones were piled, resulting a filling from the latest to earliest.

9 Caland 1900: 14 and n.8. 
However, Speyer ${ }^{10}$ in his review of Caland's translation does not support this criticism to Bloomfield's emendation, doubting that the term vișaye alone may have the meaning "in a reference".

\section{Dārila's assumption}

Curiously enough, Dārila reads in the mūla vișaye yathāmtaram, ${ }^{11}$ emended by the editors as viśaye yathāntaram, but glosses in the bhāṣya, samśaye. Caland rightly noticed that both commentators, Dārila and Keśava ${ }^{12}$ have maintained the reading vișaye all throughout.

mantrakarmadravyasamśaye yat nikrșțam ${ }^{13}$ tat pratyetavyam | brahma jajñnānam iti sūtikārișțakau prapādayati (Kauśs 28.15) iti māhākāṇ dikāsaṃdeho bhavati | karmasaṃdehe manthāntāni iti saṃdeho bhavati | bahuvacanatvāt ${ }^{14}$ | śirasi mantham upamathya (Kauśs 27.10) sūktasya pāram gatvā prayachati (KauśS 10.13, cf. 20.8) iti vidhāvevodāharișyāmaḥ|

- When a doubt arises as to the [employment] of a hymn, of a rite, or of a substance, then [all these] should be inferred from the juxtaposed context. Thus, [in the case of the sūtra] "With the hymn brahma jajñnāna, [the sacrificer] makes the pregnant woman or the one having unlucky symptoms of disease to take a few steps[, and then he gives her mantha or porridge to eat]." (KauśS 28.15), there is an uncertainty as to the hymn belonging to the great kandik $\bar{a}^{15}{ }^{15}$ There is an uncertainty as to the rite, in the case of the rites ending with mantha. [In this case the uncertainty arises] from the plural. [As for the dravya used in the actions prescribed by the sūtras:] "He stirs the mantha on the head" (Kauśs 27.10) [and] "Having completed the recitation of the hymn [1.1], ${ }^{16}$ he gives [dhānā on krṣäjina]” (KauśS 10.13, cf. 20.8), we shall cite the instances under the actual prescriptions.

10 Speyer 1901: 249. I am very thankful to Arlo Griffiths for drawing my attention to this reference.

11 ad KauśS 8.10, v. Dārila ad KauśS 46.7.

12 Jan Houben (September 2009, Kyoto) accurately drew my attention that the mūla of Keśava, which is not bracketed by the editors as being reconstructed, reads in the edition viśaye. My impression is that their policy is to regularize throughout vișaye, as in the case of the Dārila edition.

13 The editors' emendation: samnnikrșțam.

14 bahunatvāt in the MS.

15 The great book is the name of the fifth kānda of the Śaunakasamnitā (ŚS), which appears with this name in ŚS 19.23.18, a hymn extolling the Samhitā and describing its composition. v. Whitney (1962: 931) and the general introduction (1962: clvii-viii).

16 Unless otherwise specified, the hymns referred to in this paper are from the ŚS. 
Therefore, Dārila understands the difficult KauśS 8.10 as related to the confusion of a mantra, a karma or a dravya, confusion which can be avoided by referring to the adjacent context. He gives illustrations of this paribhāṣāviniyoga (application of the general rule) featuring each of the three situations. We shall subsequently analyze them.

\subsection{The hymn's confusion}

For the identification of the pratīka brahma jajñnāna denoting two Śaunakin hymns having the same beginning, 4.1 and 5.6, I refer to my presentation in the Vedic Workshop, Texas, Austin, 2007. ${ }^{17}$ As I have therein concluded, there is a paribhāșā referring to the mantraviniyoga (usage of the verse/hymn) which might help ascertaining the identity of the intended hymn:

\section{KauśS 8.21. grahaṇam ā grahaṇāt}

- [The pratika] denotes the employment of the hymn [in the rite prescribed by the subsequent sūtras] upto the next pratika [quoted in that section of the sūtra]. ${ }^{18}$

The sūtra under discussion in Dārila's exemplification, 28.15, has been hitherto much analyzed and we have shown how the meta-rule 8.21 could be applied for identifying the hymn, which is 5.6. According to the paribhāșā 8.10 this time, we are told to look in the proximate context. In the previous sütra, 28.14, a mention of "[the verses] having [the word] lakșa as an indication" (lākșālingāabhih), is made. The hymn in question is 5.5, wherein the word lākșā occurs (cf. Dārila ad KauśS 28.14) ${ }^{19}$ are 5.5 and also 4.12, where Rohinī occurring in the first verse is equated with Arundhatī, Silācī and Lākșā. Applying the rule 8.10, the hymn denoted by the pratika brahma jajñnāna in the sūtra 28.15 is 5.6.

Both paribhāṣās, KauśS 8.10 and KauśS 8.21, prescribe the reference to the closest context, one being restricted to the mantra, the other enjoining further applications. Therefore, we may assume that the understanding of the viniyoga as related to mantra application renders the paribhāṣa 8.10 redundant. $^{20}$

17 Rotaru 2016.

18 Bahulkar 1977: 38, n.133, taken up again in 1994: 5 ff.

19 Dārila, and probably following him Sāyana (under the verse 4.12.1), considers that the hymns are connected with lākșā are 5.5 and also 4.12, where Rohinī occurring in the first verse is equated to Arundhatī, Silācī and Lakșā.

20 Cf. Keśava ad KauśS 25.10 (v. bellow § 2.1). 


\subsection{The rite's confusion}

Dārila cites as the adhikāra of KauśS 8.10 the 'rites ending with mantha' (manthāntāni). A pertinent question is which are the 'rites ending with mantha'? The term is employed twice in the KauśS, at 12.4 and 18.26. Both the occurrences shall be further investigated.

\subsection{1}

KauśS 12.4. vatso virājo [13.1.33] iti manthāntāni |

Dārila under KauśS 12.4 explains:

vatso virāja ity ṛcā [13.1.33] trirjyotiṣ kurute ityādīni prónimanthah ity evam antāni manthāntāni ${ }^{21}$ karmāṇi bhavanti | na audumbaryādīny anirdeśakatvāt | sarvasāmpadaśabdena nāvyavadhānāt $\left.\right|^{22}$

- With the verse [13.1.33] [he performs the manthäntani rites]. The manthāntāni are the rites [prescribed by the rules] beginning with KauśS 11.12 and ending with KauśS 11.15. [This term is used in order] not to point out [the rules] beginning with Kauśs 11.11 [and] because there is no contiguity with the word "obtaining every desire".

A close analysis of the rules referring to manthāntāni is essential.

KauśS 11.11. audumbarādīny ${ }^{23}$ bhakșaṇāntāni ${ }^{24}$ sarvasāmpadāni|

The rites for obtaining every desire [are performed with the actions prescribed in the sūtras] beginning with KauśS 7.4 [and] ending with KauśS 7.6 [, accompanied by the recitation of 1.1]. ${ }^{25}$

21 This is the editors' felicitous emendation of ity evam mamthāmentāni.

22 This is our reading of the text which is quite corrupt: nodumbaryādinyānideśikatvātman ॥ sarvasāmpadaśabdam na navyam vadhānāt || (cf. iti nāvyavadhānāt p. 25, line 21, emended by the editors itinā vyavadhānāt and restored thus by Patyal (1974: 138)). The editors' reading: na audumbaryādīni anirdeśāt | sarvasāmpadaśabdena vyavadhānāt |

23 This is the sūtrapratīka of KauśS 7.4. Cf. KauśS 12.11 audumbaryādīni trīni | - [He performs] the three [rites] beginning with 7.4, viz. 7.4, 7.5, and 7.6.

24 Sūtrapratika of KauśS 7.6.

25 Cf. KauśS 8.21. 
For understanding this sūtra one has to refer to the paribhāṣās mentioned herein:

\section{KauśS 7.4. samidham ādadhāti |}

- [When the verb] "he places a fuel on the fire" [is used], fuel [should be understood].

For the identification of the samidhs there is another prescription, in the manner of a paribhāșā, inserted in the actual description of the medhājanana rite, a practice not unlikely KauśS’s style.

\section{KauśS 10.4. audumbarapalāśakarkandhūnām ādadhāti |}

- He places fuel on the fire, udumbara, palāśa or karkandhū (Zizyphus Jujuba). ${ }^{26}$

KauśS 7.5. āvapati vrīhiyavatilān |

- [When the verb] "he scatters" [is used] rice, barley or sesame [should be understood].

KauśS 7.6. bhakṣayati kṣīraudanapurọ̣āśarasān |

- [When the word] "he makes one eat" [is used] rice boiled in milk, sacrificial cake, or rasas [should be understood].

The rasas are prescribed by KauśS 8.19:

dadhi ghṛtạ̣ madhūdakam iti rasāh |

- The flavors are curds, ghee, and honey mixed with water.

Thus, the main actions in the rites for obtaining every desire (sarvasāmpadāni) are performed as follows: While reciting 1.1 one has to place on the fire's pile udumbara, palāśa or karkandhū. Afterwards, he offers into the fire rice, barley or sesame with the same hymn. Having recited the same hymn, he proceeds to eat either of the following plates: rice boiled in milk, sacrificial cake, curds, ghee, or honey mixed with water.

The subsequent manthāntani regulating sūtras are as follows:

KauśS 11.12. trir jyotih kurute |

- [With the hymn 1.1 $]^{27}$ [the one desiring the fulfillment of every desire] kindles the sacred fire for three [days].

26 Keśava glosses for this term 'bṛhadbadarī ‘(cf. Keśava ad KauśS 11.11).

27 Cf. Kauśs 8.21. 
KauśS 11.13. upatișthate |

- [With the hymn 1.1 $]^{28}$ [the one desiring the fulfilment of every desire] prays to deities [three times a day].

KauśS 11.14. savyāt pāṇihṛdayāl lohitam rasamiśram aśnāti |

- [With the hymn 1.1 ${ }^{29}$ [the one desiring the fulfilment of every desire] eats blood mixed with rasas (i. e. curds, ghee, and honey mixed with water) ${ }^{30}$ by means of the left hand.

KauśS 11.15. prśnimanthah |

- [With the hymn 1.1] $]^{31}$ [the one desiring the fulfilment of every desire drinks] a beverage made by stirring and mixing ingredients coming from a speckled cow. ${ }^{32}$

These are the couplets of sūtras ending with mantha, the so called manthāntāni. Afterwards eight sūtras follow prescribing different rites for obtaining every desire. The last sūtra in this ritual sequence is precisely 12.4 .

\section{KauśS 12.4. vatso virājo [13.1.33] iti manthāntāni |}

- [With the hymn] 13.1.33 [he performs the rites prescribed in the sūtras] ending with [the word] mantha.

This brings up the question: why the actions prescribed under 11.11-11.15, designated as manthāntani, and performed this time with another mantra, 13.1.33, were not mentioned subsequent to the sütra 'ending with mantha', that is 11.15. It is because the KauśS uses a combination of two methods for enjoying the rites, mantrādhikāra and phalādhikāra, ${ }^{33}$ i. e. following the Samhitā's order, and according to the portent of the rite, respectively. In the sequence of rites having as a goal the obtaining of every desire, the sūtrakāra prescribes actions which are performed with Śaunakin hymns in the Samhitā's order, from ŚS 1.1 to ŚS 13.1.33, following the mantrādhikāra method, but switches to phalādhikāra method for introducing the manthāntāni at 12.4, and resumes the former method for the next sequence of rites used for obtaining harmony, from 12.5 onwards.

This is the meaning of Dārila's comment on manthāntani too: the sarvasāmpadakarma ādhikāra holds from 11.11 to 12.4 . The term manthāntani

\footnotetext{
28 Cf. Kauśs 8.21.

29 Cf. Kauśs 8.21.

30 Cf. Kauśs 8.19.

31 Cf. Kauśs 8.21.

32 Thus translates M-W. 647, c.2 the hapax prśnimantha.

33 Cf. Dārila, Intro. v. et Bahulkar (1994: 27 ff.).
} 
is used in the sütra 12.4 to describe the sequence of rites 11.11-11.15 for the sake of brevity.

\subsection{2}

The second occurrence of manthāntāni is KauśS 18.26. For its understanding, a reference to the surrounding context is indispensable.

KauśS 18.24-26. śaṃbhumayobhubhyām [1.5 and 1.6] brahma jajñnānam [4.1] asya vāmasya [9.9] yo rohita [13.1.25] ud asya ketavo [13.2] mūrdhāham [16.3] viṣāsahim [17.1] iti salilaiḥ kṣīraudanam aśnāti | manthāntāni |

- With the mantras from salilagana, ${ }^{34}$ [that is] 1.5 and 1.6, 4.1, 9.9, $13.1 .25-26,,^{35} 13.2,16.3 .1-4,{ }^{36} 17.1 .1-5,{ }^{37}$ he eats rice boiled in milk. [With the same hymns] [he performs] the manthāntāni.

Although there is no paribhāṣā regulating the function of the manthāntāni karmāni, Keśava is consequent in prescribing in the two instances wherein these rites are mentioned, the actions from KauśS 11.11-11.15: the kindling on the fire with samidhs made of udumbara, palāśa or karkandhūna; the offering of vrīhi, yava, or tila besmeared with the residues of the oblation (sampāta), after having consecrated them with the mantra employed in the respective rite; the eating of kșiraudana, purodāśa, or rasas (i. e. dadhi, ghrta or madhūdaka besmeared with the residues of the oblation, after having consecrated them with the mantra employed in the respective rite; the fire's kindling, and watching it over three nights; the prayer to deities; the eating from the left palm blood seasoned with rasas.

Both instances analyzed under $\S 1.2 .1$ and $\S 1.2 .2$ describe sets of rites connected with the obtaining of sarvakäma. In the first instance they are to be performed with the recitation of the verse 13.1.33, in the second, with the hymns of salilagaṇa. The paribhāṣā 8.10 referred by Dārila in connection to manthāntāni rites may be applied to the sūtras 12.4 and 18.26 as follows: "The rites should be done as described subsequently (yathāntaram) in the rules ending with the word

34 This gana is not defined along with the other groups of hymns, viz. mātrnāmāni, etc, in the general paribhāṣās' section.

35 On the basis of KauśS 8.7: anantarāṇi samanāni yuktāni - the consecutive hymns having common use are to be employed [in the ritual collectively, though the sütra mentions the pratika of the first hymn in the series] (Bahulkar 1977: 35, n.126).

36 Cf. Kauśs 8.7.

37 Cf. Kauśs 8.7. 
mantha", and "The rites should be done as described in the analogous [sūtras] (yathāntaram) ending with the word mantha", respectively.

\subsection{The substance's confusion}

On the third instance Dārila cites three examples:

\subsection{1}

KauśS 27.10. prāimukham vyādhitam pratyañmukham avyādhitam śākhāsūpaveśya vaitase camasa upamanthanībhyām tṛṣnāgṛhìtasya śirasi mantham upamathyātrșitāya prayachati |

- Having placed the ill one facing the east and the healthy one facing the west, on the branches, he stirs mantha in a cup made of vetasa by means of two stirring staffs, upon the head of the person seized by thirst, and [with the hymn 2.19] he gives [that mantha] to the person who is not thirsty.

Mantha which is stirred on the patient's head it should be given, coincidentia oppositorum, to the person who is neither ill or thirsty. Mantha is the substance which has to be administered to the second person, and this may be inferred from the first action, which is expressed in the same sūtra.

It might be objected that the second mantha is a case of implicit enounce and that the application of KauśS 8.10 is not quite necessary. The confusion envisaged by Dārila consists in the fact that there is another paribhāṣa, 7.7 , restricting the usage of the verb prayachati: 'manthodanau prayachati | - When the verb "he gives" is used without mentioning the object, mantha or odana should be supplied.' In this case, the paribhāsa $\bar{a} 7.7$ is not to be applied, but 8.10. Or otherwise said, here the paribhāșā 8.10 restricts the application of 7.7 .

\subsection{2}

KauśS 10.13. sūktasya pāram gatvā prayachati |

- Having completed [the recitation] of the hymn [1.1] he gives [dhānā on krṣnājina].

The objects are taken from the immediately preceding sūtra 10.12, within the rite for medhäjanana, which mentions them explicitly, and from where they could 
have been inferred through anuvrtti. By applying KauśS 8.10 Dārila prevents the application of KauśS 7.7.

\subsection{3}

Kauśs 20.8. sūktasya pāram gatvā prayachati |

- Having completed [the recitation] of the hymn [3.17] he gives [the plough].

The object should be supplied from the prior sūtra, 20.7, where the verb "he plows” occurs. By applying KauśS 8.10, the viniyoga of KauśS 7.7 is prevented. However, the main 'doubt' for Dārila is not concerning the object, but the hymn to be employed, and he has explained that ambiguity under KauśS 20.1 .

KauśS 20.1. sīrāyuñnjanīti [3.17] sūktasampratyayo 'viśeșanirdeśāt | senāgnimanthanasūktavat |

- The hymn 3.17 is appropriately used on account of the indication of similarity. Like in the case of the hymn [employed] in the churning of the fire, in the martial rite.

The mentioned martial rite is prescribed at KauśS 16.9-14, and the actions are to be carried out with the entire or partial recitation of the hymn 8.8. Dārila explains the employment of the hymn:

sūkte rci samānāditvāt | manthanasamidādhānayoḥ prayogārtham | aśvatthabandhakayor agnim manthati ity atra ṛk | sapatnakṣayaṇīrādadhāti ity atra sūktam |

- The hymn and the verse is designated by the same [pratika]. Its employment is in the rite of putting on fuel for churning the fire, [as follows]: the verse 8.8.1 at KauśS 16.11, the hymn 8.8 at KauśS 16.14.

Coming back to Dārila's comment under KauśS 20.1 on the employment of the hymn section-wise, in the agricultural rite prescribed by Kauśs 20.1-8 ff., he gives the following explanation:

sīrāyuñnjantīti [3.17] yojanapratanayor āvartane manthanavadvibhāgaḥ syād vacanavirodhah pāram gatvā ity ca |

- The hymn 3.17 is used repeatedly in the yoking [of the bulls] and the measuring of the ground; there should be a section like in the fire's 
churning and an apparent contradiction of the enounce "having completed the hymn" (Kauśs 20.8).

Dārila does not explain again under KauśS 20.8 - and this speaks by itself about his astute scholarship - which is the hymn to be employed herein, but he aptly quotes the paribhāṣā 8.21 in order to ascertain the same. ${ }^{38}$ He says that the hymn under discussion, 3.17, should be used until the next mentioned mantra that occurs in the sūtra 20.10, namely the last verse of the hymn 3.17, the verse number eight. Yet, he says that:

uparyuktasya śeșasya sūktasyāntam gatvā kartā karșakebhyah prayachati halam |

- Having completed the remaining portion of the hymn in question, the priest gives the plough to the farmers.

\section{Keśava's assumption}

Keśava, likewise Dārila, ${ }^{39}$ understands the paribhāṣa 8.10 in the same spirit, elucidating a possible confusion of mantra or dravya with the help of a juxtaposition.

mantradravyasaṃśaye saṃnidhānam grhìtavyam \|| yathā lomāni (KauśS 13.3) hastiromāṇi ${ }^{40}$ yathā vidma śarasya iti pramehaṇam badhnāti (Kauśs 25.10) \|

- When in doubt, the close context should be referred to. Thus [it is the

38 The hymn ŚS 3.17 is mentioned once, at KauśS 20.1, in the beginning of the section dedicated to the rites for good ploughing, it is inferred through the subsequent sūtra, 20.2, it is followed by an unidentified pratika at 20.3, and by a whole verse from 8.18.6 at 20.5 (Griffiths 2004: 58 indexes this Paippalāda mantra quotation in the entry KauśS 820), again by one unidentified verse and one pratika at 20.6 and 20.7, respectively. Which hymn should then be employed at Kauśs 20.8? According to 8.21, it should be the one designated by the last mentioned unidentified pratīka. Yet, Dārila says it is ŚS 3.17. How can we account for this? Should it be the case that Dārila is counting only the Saunakin hymns? What was then his approach towards the hymns of the other Atharvavedic śākhā?

39 Keśava's explanation on 8.10 looks like an abridged version of Dārila's, yet he quotes independently from the latter instances in support of his assumption. It is worth noticing the superiority of Dārila's understanding of the sutra 8.10 and his outstanding scholarship, as noted in this paper under $\S 1$ 1.3.3. For a contrary opinion see Caland 1900: v. and recently Meulenbeld 2004: 296.

40 Cf. Keśava ad KauśS 13.3, MS. Ba. The other MSS. read hastilomāni. 
case with] "hair" (KauśS 13.3), [where it should be inferred] "elephant's hair". Thus [it is the case in] "[With the hymn] vidmaśarasya he ties the pramehana at [the patient's neck]” (Kauśs 25.10).

\section{1}

Lomāni is the sūtrapratīka of KauśS $13.3,{ }^{41}$ an elliptic enounce which can be completed from the adjacent sūtra, within a rite for obtaining splendour.

\section{Kauśs 13.2. hāstidantam badhnāti |}

- [With the hymn 3.22], ${ }^{42}$ [the warrior] ties on an amulet of ivory. KauśS 13.3. lomāni jatunā samdihya jātarūpenāpidhāpya |

- [With the hymn 3.22], ${ }^{43}$ [he ties on the warrior an amulet made of the elephant's] hair, after having besmeared [the hair] with lac, and having covered [the same] with gold, [and after having consecrated the amulet with the hymn in question, ${ }^{44}$ and on which the remnants of clarified butter have been poured ${ }^{45}$.

Keśava considers that the difficulty concerns the identification of the substance, namely hair, which should be from an elephant, the mention of the latter occurring in the previous sūtra. Although Dārila does not specifically refer to the adhikāra of 8.10 on KauśS 13.3, he glosses here badhnātīti vākyaśeșah, supplying thus the verb from the adjoining sütra. Caland also thinks that the verb badhnāti should be added from 13.2, likewise in KauśS 26.21, which will be further discussed.

2.2

KauśS 25.10. vidmāśarasya iti pramehaṇa badhnāti |

- [With the hymn] vidmaśarasya he ties the pramehana at [the patient's neck].

41 This has passed unnoticed by Keśava's editors.

42 Cf. KauśS 8.21. The hymn is mentioned at KauśS 13.1.

43 Cf. Kauśs 8.21.

44 Cf. KauśS 7.15.

45 Cf. KauśS 7.19. 
Under the sūtra 25.10 Keśava glosses for the hymn employed 'vidmā śarasya dvitīyena'. There are two hymns having the same beginning designated by this pratika, 1.2 and 1.3. By referring to the close context, one can distinguish the right hymn to be employed. The pratika occurs at 25.6 and it must be inferred throughout the sütras 25.7, 8 and 9, by the rule 8.21 , as seen previously. Since the pratikka is mentioned anew at 25.10 it means that it denotes another hymn, namely 1.3. The application of the paribhāșā 8.10 is redundant in this case.

\section{Viniyoga paribhāṣā}

Besides the viniyogas discussed by Dārila and Keśava under KauśS 8.10 and explained above by us, there are other instances whereto the paribhāṣā under discussion may be applied.

\section{1}

The sütra 13.1 is an instance briefly discussed by Caland, in connection with the paribhāṣā 8.10. It prescribes a rite for attending splendor (tejaskāmah).

KauśS 13.1. hastivarcasam [3.22] iti hastinam |

Dārila glosses:

yadi kṣatriya upatișțhate | agnim upatișţhate antaratvāt |

- When the warrior [sees an elephant] he does the service to the fire. "He does the service to the fire" (KauśS 12.14) [should be substituted] from the previous passage.

Thus, a whole action is to be supplied from an antecedent sūtra, 12.14, which prescribes a rite having the same purport, varcaskāmah. ${ }^{46}$ The prescription 13.1 reconstructed is as follows:

With the hymn 3.22, [the warrior, having seen] an elephant[, does the service to the fire].

46 Thus glosses Keśava under 12.4 . 


\section{2}

In a rite against the demons' possession, KauśS 25.33 prescribes:

25.33. ukto homah |

- The offering has been prescribed.

Dārila explains:

yathāntaravacanāt | asya homasyedhmābarhișah śālāyām āsaktam ||

- [Having found] the grass and the fuel fastened in the house, [he should do] the homa, as per the juxtaposed context.

Keśava is more explicit as to the reference: vīinatūlam ityādi, which is the sūtrapratìka of KauśS 25.30. The rule contains the verb juhoti:

KauśS 25.30. vīrinatūlamiśram ingiḍam prapuțe juhoti |

- He offers ingiḍa mixed with vĩrina by means of a large folded leaf.

Dārila under 25.31 comments that the adhikāra of Kauśs 25.31 (idhmābarhih śâlāyām āsajati), is 25.32 and 25.33, hence the performance of the homa should be put in connection with the objects mentioned herein, idhma and barhi.

The paribhāṣa 8.10 could be applied to the confusing succinct sūtra 25.33, by supplying thus the paraphernalia necessary in the homa: offering of the substances mentioned at 25.30 into the fire kindled with the combustibles stated at 25.31 .

\section{3}

Under KauśS 26.21. Dārila applies the paribhāṣa 8.10 for elucidating the action implying the usage of an object particularly described in 26.16.

KauśS 26.21. kroḍalomāni jatunā samidihya jātarūpeṇāpidhāpya |

- [With the hymn 1.12] ${ }^{47}$ [he ties to the patient] [an amulet made of] hair from the bosom [of a red bull], ${ }^{48}$ after having besmeared [the hair] with

47 Cf. KauśS 8.21. The hymn is mentioned at KauśS 26.14.

48 Cf. Keśava: vṛșabhahṛdayalomabhih. For the translation of the whole sūtra v. Bahulkar (1994: 112-113). 
lac, and having covered [the same] with gold, [and after having consecrated the amulet with the hymn in question, ${ }^{49}$ and on which the leftovers of clarified butter have been poured ${ }^{50}$.

Dārila says:

badhnāti yathāntaratvāt |

- He ties on [an amulet] as per the paribhāșā 8.10.

The verb badhnāti is mentioned in KauśS 26.16, quite far from the sūtra under discussion, nonetheless, within the framework of the same medical rite for curing jaundice and heart diseases.

\section{4}

The rite for removing the worms in the child's body has the following action:

KauśS 29.21. grāmāt pāmsūn |

Dārila:

utkarati | āharati grāmāt pāmsūn upamathya | yathāntaratvāt |

- He digs and brings dust from the village, having rubbed it. As per analogous passage.

The term upamathya is the sūtrapratīka of KauśS 27.18, from a rite for removing the worms:

KauśS 27.18. savyena dakșināmukhah pāmsūn upamathya parikirati |

- [With the hymn 2.31], facing the south, he rubs the dust by means of the left hand and scatters it around.

Thus, the rendering of 29.21 would be:

[With the hymn 5.23] [he digs] dust from the village, [rubs it by left hand, and scatters it around the patient].

49 Cf. KauśS 7.15.

50 Cf. Kauśs 7.19. 
The action to be performed with the dust in a rite for removing the worms is to be supplied from the closest sūtra wherein the dust is referred, 27.18, from a rite with a similar function, over an interval of 19 medical rites having different purposes. $^{51}$

\section{5}

The sūtras 40.7-9 describe a second rite in a section dedicated to charms for directing the course of a river (nadīpravāhavidhi).

KauśS 40.7. mārutaṃ kṣirraudanaṃ mārutaṣ̣̂tạ̣ mārutaị̣ paristīrya mārutena sruvena mārutenājyena varuñāya trir juhoti |

- [With the hymn 3.13] $]^{52}$ he offers thrice oblation of Marut's ghee to Varuna by means of Marut's ladle, Marut's rice boiled with milk, Marut's ghee, having strewn around Marut's grass. ${ }^{53}$

KauśS 40.8. uktam upamanthanam |

- The act of stirring is described [at KauśS 27.10]. ${ }^{54}$

Dārila glosses:

vaitase camase upamanthanam | te ca upamanthanyau yathāntaratvāt |

- He stirs the mantha on a cup made of vetasa. The two stirring staffs are as per the anterior passage.

The next sütra prescribes what is to be done with the mantha so prepared:

KauśS 40.9. dadhimantham balim hṛtvā samprokṣaṇībhyāṃ prasiñncan vrajati |

- Having carried along an oblation consisting of milk with mantha, by means of two sprinkling strainers, he walks pouring out water.

51 This hiatus is due to the manträdhikära order of the rites.

52 Cf. Kauśs 8.21.

53 Mārutāni are a specific class of rites intended to bring rain, prescribed by KauśS 41.1-7. "The three offerings to Varuna are given according to the manner mentioned at KauśS 23.1-3, where the first two offerings are given with two different verses, and the third one is given with the recitation of both.” (Bahulkar 1994: 115).

54 For this sūtra v. supra $\S 1.3 .1$. 
The past passive participle uktam of KauśS 40.8 already refers to a previous instance wherein the upamanthana has been described. The application of Kauśs 8.10 is therefore redundant.

\section{6}

KauśS 41.10. pūrvāsvaṣā

- Under the constellation Pūrvāṣāḍhā he digs out a hole.

KauśS 41.11. uttarāsu saṃcinoti |

- Under the constellation Uttarāṣāḍhā he fills this up.

KauśS 41.12. àdevanam samstīrya |

- He spreads the board for gambling [in that filled up hole].

KauśS 41.13. udbhindatīmsamjayantīm [4.38.1] yathā vṛksam aśanir [7.50.1] idam ugrāyeti [7.109.1] vāsitān akșān nivapati |

- [Reciting the hymns] 4.38.1, 7.50.1, and 7.109.1, he throws the dices which have been "dressed", i. e. [kept in milk and honey for three nights, beginning with the thirteenth day of the latter half of the month, besmeared with the leftovers of the oblation, and consecrated with the hymns in question].

This is a rite for success in gambling (dyutajayakarma). Dārila comments on vāsana:

nanv atra vāsanasamyogāt dadhimadhuni vāsanam yathāntaratvāt |

- Now as concerning vāsana, it should be understood 'a dressing in honey and milk', as per the previous (?)/analogous instance.

The instance intended by Dārila is the paribhāṣa 7.19 .

KauśS 7.19. trayodaśyādayas tisro dadhimadhuni vāsayitvā badhnāti |

- [When the words] 'having put on, he ties' [are used] [one should understand that] [the amulet is to be kept] in honey and milk for three nights beginning with the thirteenth day of the latter half of the month].

In fact the sūtra 41.13 becomes clear with the help of three paribhāṣās. The second is 7.15: āśyabandhyāplavanayānabhakșāni sampātavanti | "- In the acts of eating, binding, bathing, riding [a vehicle], consuming, [the substance in question should be anointed with] the leftovers of the oblation, i. e. the clarified butter”; and the third 7.16: sarvānny abhimantryāni | “- All these [actions, i.e. 
those mentioned under 7.15, should be done] having been consecrated with the [relevant] mantras”.

We suspect that Dārila's reference to 8.10 is erroneous. vāsanam already functions as an indication for the paribhāṣa $\bar{a} 7.19$.

\section{7}

The sūtra 46.7 prescribes a rite for warding off the evil effects of seeing certain birds:

KauśS 46.7. mantroktāni patitebhyo devāh kapota [6.27.1] rcā kapotam [6.28.1] amūn hetir [6.29.1] iti mahāśāntim àvapate |

- [With the verses] 6.27.1, 6.28.1, and 6.29.1 he performs the mahāsāanti [and] pours out śäntyudaka [to ward off] against the birds mentioned in these verses.

Keśava gives an account of the ritual performance. The sāntyudaka is duly prepared, with the hymns mentioned in the respective section. ${ }^{55}$

Dārila has a very interesting statement about the viniyoga paribhāṣā 8.10:

mantroktā ulūkakapotāḥ | tebhyaḥ anucitadeśagatebhyaḥ yadaśamaṃ ${ }^{56}$ tan niṣkrayāyedam ucyate | etāni trīni mahāśāntim cānārabhyavādoktam | na cakāro 'tra pațhitaḥ gamyamānatvāt | krtyāpratiharaṇavat | tattulyanirdeśaś cobhayoh samānakarmatvāt | viśaye yathāntaram iti | tasmāt [sic! tasmād] agratạ prokṣan ityādeh (KauśS 39.8) krtyāpratiharaṇavat mābhūr iti (Kauśs 39.9) ity antāt | niši 'iti cāvayavagrahaṇād vidhānāc ceha kṛtyāyāḥ avamucyoṣṇișī iti kṛtyānidarśanāt prāpnuyāt | iha tv arthavattvān nivarteta || - [The birds are those] mentioned in the hymns, i. e. owl and pigeon. The following is prescribed for those birds to fly to improper places and to expel them to an unquiet place. The mahāśānti is expressed without the reference of " $c a$ " to these three [hymns]. The conjunction " $c a$ " is not read here from the act of that who is being gone, likewise in the rite of expelling the witchcraft. That similar specification of both " $c a$ " is due to the analogy of

55 The preparation of the śāntyudaka is described at Kauśs 9.1-10., and with the addition of these three. In the night he sprinkles around up to the place where the birds have been seen sitting, reciting certain kalpaja mantras. The priest besprinkles the officiant and makes him sip śāntyudaka.

56 This is our emendation to yadaśamām tạ̣ niṣkriyayedam. The editors read yadaśarma tan niṣkrayāyedam. 
the rite. For it is said "In case of confusion, [it should be understood] as per the analogous instance". On this basis, likewise in the rite of expelling the witchcraft, it should begin with "[he walks] forward sprinkling around" (KauśS 39.8) and end with “on me, you, Earth!” (KauśS 39.9). It should result "in the night" from taking a part from the prescription and here "having taken off his shoes, wearing a turban" from the witchcraft, from the injunction concerning the witchcraft. However, here the connotation is missing.

Dārila refers to 39.8 and 39.9, a rite for removing the effects of the witchcraft (abhicāraradoșān), in order to complete the elliptic sūtra under discussion.

KauśS 39.8-9. niśy avamucyoṣṇ̄ṣyagrataḥ prokṣan vrajati | yatāyai yatāyai śāntāyai śāntivāyai bhadrāyai bhadrāvati syonāyai śagmāyai śivāyai sumangali prajāvati suśīme $e^{57}$ 'aham vā mābhūr iti |

- At night, having taken of his shoes, wearing a turban, he walks forward sprinkling [śāntyudaka], ${ }^{58}$ [reciting] "For the self-controlled one, for the self-controlled one, for the peaceful one, for Sāntīvā, for the auspicious one, $\mathrm{O}$, Bhadrāvatī, for the pleasant one, for the kind one, for the holy one; $\mathrm{O}$, you, lucky one, $\mathrm{O}$, you, having offspring, $\mathrm{O}$, you, reliable one! I, or on me, you, Earth!"59

According to him these two rites are analogous, hence, on the basis of the paribhāșā 8.10, the elliptic parts in 46.7 should be taken from 39.8-9. Caland has discerned the new meaning of yathāntaram in this peculiar fragment, as "so wie an den analogen Stellen", and considered that it might be the sense to be applied to all its occurrences. In fact this new meaning is a secondary one, a sense adapted by the commentator in his endeavor to fit the viniyoga of the paribhāṣā 8.10 to the context under discussion.

57 Cf. KauśS 24.14 and 76. 2. Bloomfield reads susìme.

58 Mentioned in the previous sūtra, 39.7. dūșyā dușir asi [2.11.1] ye purastād [4.40.1] îsāānām tvā [4.17.1] samam jyotir [4.18.1] uto asy abandhukṛt [4.19.1] suparnas tvā [5.14.1] yām te cakrur [5.31.1] ayam pratisaro [8.5.1] yām kalpayantīti [10.1.1] mahāśāntim āvapate.

59 This is a tentative translation of a maybe untranslatable "hocus-pocus" incantation (Caland 1900: 134, n. 7). Caland considers that the series of feminine nouns in Dative may refer to krtya or to $b h \bar{u}$. 


\section{8}

KauśS 46.22. samsamid [6.63.4] iti svayamprajvalite 'gnau |

- When the fire kindles by itself, he [offers] in the fire [with the hymn] 6.63.4.

Dārila refers to 45.1 on the basis of yathāntaratvāt. This is also a prāyaścitta performed in the vaśâśamana, if the cow is found pregnant.

KauśS 45.1. yady așțāpadī syād garbhamañnjalau sahiraṇyạ̣ sayavaṃ vā ya ātmadā [4.2] iti khadāyām tryaratnāvagnau sakṛjuhoti |

- If it is found with eight legs (i. e. pregnant), [having taken] in the folded hands the foetus with gold or with barley, he kills it while reciting the hymn 4.2 and sacrifices it at once in the fire pit of three aratnis.

This is another instance where paribhāṣa 8.10 may be applied based on the analogy of the rites, that are both expiations.

\section{Conclusions}

Although much work was done since the first translations of individual chapters and the editio princeps of the KauśS, all meant to improve the present edition, remarkable results were not achieved in regard to the investigation into the sütra text's composition.

The state of art is not much beyond what Bloomfield stated in the introduction to his edition:

I do not venture to assert that there was a time, when there existed a corresponding treatise of approximately the same scope, which would justify us in speaking of an earlier form of the text, or in claiming, that certain parts were added after the text left the hands of the last redactors. $^{60}$

Pushing one step forward, Bahulkar concluded his refutation to Bloomfield's judgment on the composition of the KauśS with the following remark:

60 Bloomfield 1889: xxii. 
However, there is ground to assume that there must have been an earlier form of the KauśS, approximately of similar scope, but different from that of the present text. ${ }^{61}$

According to Bloomfield ${ }^{62}$ the first six kandikās are interpolated to the nucleus of the KauśS, which in fact starts at the 10th kandikā, with medhājanana. He considers that those kandikās might have well fit at the beginning of the section prescribing the proper grhya ritual, between the $52^{\text {nd }}$ and $53^{\text {rd }}$ kaṇikās. Bahulkar refutes his argument that the rites of the full moon and new moon was described in the beginning of the KauśS in deference to the śrauta tradition, on the basis that this rite serves as the archetype for all the domestic rites, hence it is described at the outset. ${ }^{63}$

The thirteenth adhyāya, on omens and portents was considered by Weber as a later incorporation, ${ }^{64}$ and by Bloomfield an independent piece added to the KauśS due to its consistency to the ātharvanic matters. ${ }^{65}$ Bahulkar goes further envisaging the existence of a tradition on omen and portents in the àtharvanic quarters, formally recognized at a later date and hence incorporated in the Kauśs. 66

The fourteenth adhyāya, treating on subjects occurring in the previous chapters, is unanimously recognized as a later addition to the Kauśs. ${ }^{67}$

These much has been said, according to my knowledge, about the composition of the KauśS. Nowhere it is expressly said that the kandikās 7-8, especially the paribhāṣa section 7.1-8.22, might be an afterthought added to the corpus of the KauśS, whatever the latter might have been. Prof. Bahulkar has hinted to that in 2002 while reading individually for me the text of the Kauśs.

The reason for the addition of the entire section or at least of certain paribhāșās of this section was evidently the need for clarity and consistency of the composite sutra-text. ${ }^{68}$ One more argument in favor of the later addition of the

61 Bahulkar 1994: 26.

62 Bloomfield 1889: xxvii-xxviii.

63 Bahulkar 1994: 20-21.

64 Weber 1859: 345, 384.

65 Bloomfield 1889: xxiii-xxiv.

66 Bahulkar 1994: 24.

67 Bloomfield 1889: xxv-xxvi; Bahulkar 1994: 26.

68 Similarly, a list of twenty-three Upanișads (although only eighteen announced, as against the fifteen listed in the Caranavyūha) was incorporated into the Caranavyūhopanișad, the Paippalādin version of the so-alleged Śaunakin Caranavyūha (Griffiths 2007: 141-194). 
paribhāṣā section is the fact that the self-alleged paddhati Ātharvan̄iya Paddhati, which comments on the first set of special rules, ignores the second set. ${ }^{69}$

Out of the sixteen above discussed cases whereto the paribhāṣa 8.10 might be applied, we may rule out from the outset the two instances of 'mantra's confusion', mentioned so by Dārila and Keśava as not genuine viniyogas (under $\S 1.1$ and $\S 2.2$ ). Dārila's application of 8.10 to KauśS 41.13 (under $\S 3.6$ ) seems also erroneous, and to KauśS 40.9, redundant (under $\S 3.5$ ). From the remaining twelve instances, one refers to an ellipsis supplied from the same sütra (under $\S$ 1.3.1), three others imply the ākānisșita (expected term) from the next sütras (under $\S$ 1.3.2; $\S 2.1$; $\S 3.1$ ) and one, by maṇūkaplūtī (reference to a distant passage), from a close sūtra (under $\S 3.2$ ).

In seven other instances (under $\S 1.2 .1, \S 1.2 .2, \S 1.3 .3, \S 3.3, \S 3.4, \S 3.7$, $\S 3.8$ ) the enounce is completed with terms and actions supplied from quite remote passages. On this basis, we may safely conclude that yathāntaram does not mean that the ellipsis should be inferred "as per the adjacent passage", but it rather points to the "anterior passage", regardless their juxtaposition. Furthermore, in the case of the juxtaposed sūtras, both, the ākāinksita and the reference are circumscribed within the same rite, whereas in the other cases, of indication to remote passages, they are based on the analogy of the rite or of the action. Hence Caland's estimation over the meaning of 8.10 as "so wie an den analogen Stellen" might be only partially accepted. A clause should be added, "as per the analogous passages mentioned previously in the KauśS". This latter clause amounts to a conscientious effort of composing the rule 8.10 after a perusal of the whole sūtra-text. This paribhāșā was called to account for supplying the deserved term or the missing action to a variety of situations bearing very little in common. Dārila has considered the "doubt" baffling the elliptic sūtras and tried to remove it by applying 8.10 even in the cases where these sūtras were not so "doubtful" and where the ellipsis could be easily filled in by means of anuvrtti or by implicit enounce. ${ }^{70}$ Hence he might have read in earnest throughout viśaye, but since the codex unicus records the reading vișaye, the former becomes a mere hypothesis.

69 Cf. Bloomfield 1885: 375, n. †.

70 For a critique of the traditional and modern sūtra exegetes' unnecessary supposed additions to the succinct enounce v. Renou (1963: 187): "Mais il faut se garder de penser que tout ce qu'ajoutent entre parenthèses des traducteurs comme Oldenberg ou Bühler, tout ce que suppléent les commentateurs indiens, passes maitres dans l'art du vākyaśeșa, répond à une réelle ellipse dans le texte originel: ce sont les commodités de nos langues ou quelque intention pédagogique qui nous amènent à multiplier les parenthèses.” 
It might be that Bloomfield, and by all means Bahulkar (1990: 122), were lead by Dārila's commentary and emended viṣaye to viśaye. As it was shown above, the meaning of the enounce converges to the lectio vișaye.

\section{KauśS 8.10. vișaye yathāntaram |}

- In case of a reference [it should be taken] as per the analogous passage mentioned previously [in the Kauśs].

\section{Bibliography}

\section{Manuscripts}

Ātharvanīya Paddhati MSS: Accession no.1495 and 1496. Staatsbibliothek: Berlin.

Ätharvanīya Paddhati MSS: Accession no. 1870-71. Bhandarkar Oriental Research Institute: Pune. Kauśikasūtra MSS: Accession nos. 4/1866-68, 5/1866-68. Bhandarkar Oriental Research Institute: Pune.

Kauśikasūtra MSS: Accession nos. 889 and 6854. Oriental Institute: Baroda. Kauśikasūtra MSS: Accession nos. 177 and 178. Staatsbibliothek: München.

\section{Primary Sources}

Bloomfield, Maurice (1889): "The Kauśika Sūtra of the Atharva Veda. With Extracts from the Commentaries of Dārila and Keçava". Edited by M. Bloomfield. Journal of the American Oriental Society 14: v-lxviii, 1-422.

Dārila = (1972): Kauśikasutra-Dārilabhāșya. Critically Edited for the First Time on the Basis of a Single Codex which is Reproduced by Offset Process. Edited by Diwekar, H.R., V.P. Limaye, R.N. Dandekar, C.G. Kashikar and V.V. Bhide. Poona: Tilak Maharashtra Vidyapitha.

Keśava = (1982): Keśava's Kauśikapaddhati on the Kauśikasūtra of the Atharvaveda. Critically edited by Limaye, V.P., R. N. Dandekar, C.G. Kashikar, V.V. Bhide and S.S. Bahulkar. Pune: Shri Balmukund Sanskrit Mahavidyalaya Research Series 1.

ŚS = Vishva Bandhu (ed.) (1960-1964): Śaunaka Saṃitā. Atharvaveda (Śaunaka) with the Pada-pātha and Sāyañācārya's Commentary, edited and annotated with text-comparative data from original manuscripts and other Vedic works by Vishva Bandhu. Part I (Kāṇ ̣̣as I-V) 1990 [II ed., I ed. 1960], Part II (Kāṇḍas VI-X), 1993 [II ed., I ed. 1961], Part III (Kāṇụas XI-XVIII) 1994 [II ed., I ed. 1961], Part IV, Fasc. I (Kāṇḍas XIX-XX) Fasc. II (Mantra, Pada, Ṛși, Devatā, and Chanda Indices), 1964. Hoshiarpur: Vishveshvaranand Vedic Research Institute Series 13-17. 


\section{Secondary Sources}

Bahulkar, S. Shrikant (1977): Bhaișajyāni in the Kauśika Sūtra. Ph.D. Thesis. Pune: University of Pune (unpublished).

Bahulkar, S. Shrikant (1994): Medical Ritual in the Atharvaveda Tradition. Shri Balmukund Sanskrit Mahavidyalaya Research Series No. 8. Pune: Tilak Maharashtra Vidyapeeth.

Bahulkar, S.S., Dharmadhikari, T.N., Shastri, R.S., Jain, N.P., (1990: 122) Vedic Texts: A Revision. Professor C.G. Kashikar Felicitation Volume, Edited by S.S. Bahulkar, Delhi: Motilal Banarsidass.

Bloomfield, Maurice (1885): "The Position of the Vāitāna-Sūtra in the Literature of the AtharvaVeda". Journal of the American Oriental Society 11: 375-388.

Caland, Willem (1900): Altindisches Zauberritual, Probe einer Uebersetzung der wichtigsten Theile des Kauśika Sūtra. Verhandelingen der Koninklijke Nederlandse Akademie van Wetenschappen. Nieuwe Reeks Deel III. No. 2. Amsterdam: J. Müller.

Griffiths, Arlo (2004): "Paippalāda Mantras in the Kauśikasūtra." In: The Vedas: Texts, Language and Ritual. Proceedings of the 3rd International Vedic Workshop. Edited by A. Griffiths and J.E.M. Houben. Groningen: Egbert Forsten, 49-99.

Griffiths, Arlo (2007): "The Ancillary Literature of the Paippalāda School: A Preliminary Survey with an Edition of the Caranavyūhopanișad." In: The Atharvaveda and its Paippalādaśākhā. Historical and Philological Papers on a Vedic Tradition. Edited by Arlo Griffiths and Annette Schmiedchen. Indologica Halensis. Aachen: Shaker Verlag, 141-194.

Meulenbeld, G. Jan (2004): "Āyurveda and Atharvaveda: Their Interrelationship in the Commentaries on the Kauśikasūtra." In: Du corps humain au carrefour de plusieurs savoirs en Inde, Mélanges offerts à Arion Roșu par ses collègues et ses amis a l'occasion de son 80e anniversaire. Stvdia Asiatica. Volumes IV (2003) -V (2004). Bucarest/Paris, 289-312.

Patyal, Hukam C. (1974): "Remarks on the Kauśikasūtra with Dārilabhāșya." Bulletin of the Deccan College Research Institute 34.1-4: 134-142.

Renou, Louis (1963): “Sur le genre de sūtra”. Journal Asiatique 251.2: 165-216.

Rotaru, Julieta (2010): “Towards a Methodology of Applying the paribhāṣās in the KauśikaSūtra (I).” Acta Orientalia Vilnensia 9.2 (2008): 57-82.

Rotaru, Julieta (2016): “'The bráhman that Was First Born Old ...' As It Was Known by the Atharvavedins." In: The Vedas in Indian Culture and History. Edited by Joel Brereton. Alti Studi di Storia intellettuale e delle Religioni Series. Firenze: Società Editrice Fiorentina, 319-333.

Speyer, J.S. (1901): Review of Caland 1900. Museum. Maandblad voor Philology en Geschiedenis. No. 9, Lund, 248-251.

Weber, von Albrecht (1859): Zwei vedische Texte über Omina und Portenta. Berlin: Druckerei der Königlichen Akademie der Wissenschaften, 320-413.

Whitney, William Dwight (1962) [I Indian reprint; I ed. Cambrige, Mass. 1905]: AtharvavedaSamhitā. Translated into English with Critical and exegetical Commentary by William Dwight Whitney, Revised and Edited by Charles Rockwell Lanman, two volumes, First half Books I to VII, Second half Books VIII to XIX. Delhi: Motilal Banarsidass. 